\title{
Editorial
}

\section{Spaces for gender and power}

\author{
Claudia Mora ${ }^{1}$ and Daniela Cáceres ${ }^{2}$ \\ Dossier coordinators: Gender, power and inequalities
}

Temas Sociológicos Journal, N²2, 2018.

This special number of Temas Sociológicos Journal addresses the power relations respect to gender at the moment of organizing and distributing social resources in labor market, in meanings conditioning the incorporation of their issues and demands in the public agenda, and in sociopolitical regimes that contribute to gender violence, one of the most crude manifestations of hierarchy and inequality in this area. In this dossier, entitled "Género, Poder y Desigualdades" (Gender, Power and Inequalities), the selected works are part of the reflection by social sciences about gender and feminisms and it raises a discussion around subjective and social effects of generic differentiation, the socio-political contexts in which gender/power relations are developed, as well as their multiple daily manifestations.

This issue, convened months before the so-called "feminist May" in Chile, enlightens the prolific reflection about the production processes of gender difference that, invisible due to their

Doctor in Sociology by the Northeastern University, United States. Researcher and professor in Universidad Academia de Humanismo Cristiano, Chile. Contact: claudiamoradelvalle@gmail.com

2 Doctoral student in Universidad Alberto Hurtado, Chile. Contact: dcaceres@ uahurtado.cl 
everyday nature, undermine the democratizing efforts that social movements have promoted in Chile -and in the region- in the last decades (Mora, 2013). The pressure of the recent national movements revealed arbitrariness and gender violence, generating promising institutional commitments. However, the backlash that usually accompanies challenges to groups monopolizing resources and power structures (Mansbridge and Shames, 2008) is often based on the legitimacy of a natural order for gender in subjects' daily practices.

Social, economic and political systems developed in relation to the interests of power groups do not require the consent or even the awareness of the privilege of some people; nor force to act against their own interests. However, the loss of power triggers resistances expressed in violence and discredit, and, more omnipresent, in cultural war: claims about excessiveness of changes, their excessive speed and, fundamentally, in relation to the need of preserving social values defining and identifying a nation (ibid). This battle is forged in daily practices of gender differentiation, in which fighting for social justice is often framed in purely value-based challenges.

This special issue of Temas Sociológicos Journal addresses spaces where differences are reproduced, as well as processes reiterating the group disadvantages of women, focusing on three central dimensions: labor market, gender violence and normative transgression to woman as significant. The first three articles analyze gender regimes that regulate the incorporation and labor mobility of women in Chile. The Chilean labor market is one of the institutions that most clearly reflects social inequalities, since it locates resources - income, authority, prestige, for example by virtue of formal criteria, such as accumulated cultural capital, but, mainly, by virtue of informal criteria, such as participation in specific social groups. Gender, social class and national origin, among others, condition the position of workers in the labor structure, and, in the case of women, their position in these structures reflects patterns of exclusion, while concentrating them in 
certain activities and occupational hierarchies (Valenzuela and Mora, 2009).

This number includes as contribution specific case studies in two economic activities: mining and services, first addressing the limitations of public and institutional policies for incorporating women to the workplace; then, implications gender equality has on the labor life of professional and university women, and thirdly, significance of female leadership at women's own vision. In this way, this section contributes to discussing some fundamental aspects in order to understand exclusion mechanisms from work: limitations of inclusive policies in front of the significance of gender for workers and employers challenging them; reiteration of the linking between the reproductive aspect with expectations and evaluation of the female leadership, and the interference of subjective conceptualizations in the "working" identity of Chilean women.

The first article, entitled "Gender Equity in the Chilean Large Copper Mining. Experiences of female labor insertion in masculinized spaces," by Gómez and Angelcos, states that, despite the implementation of public and institutional policies to promote the integration of women in the field, fundamental barriers persist to the incorporation of women in mining, as social borders delimiting the segregation of women to stereotyped works by gender. Authors analyze how labor stereotypes associated with masculine and feminine, and the relationship between being a woman and being a mother, define activities and jobs for men and women within the mining world, privileging distinctions referring to bodies and "innate" intellectual abilities.

From twenty in-depth interviews to workers in El Teniente and Chuquicamata divisions, Gómez and Angelcos show that stereotypes associated with female and male work constitute symbolic boundaries that allow the integration and legitimization of women in mining activities in spaces adequate to the symbolic definition of "the feminine," for example, in manage- 
ment and administration tasks in a mining company. However, these same stereotypes reinforce the segregation of women in the case of work in the field. The authors argue that "the transfer of familiar logics to the interior of work -based on a paternalistic relationship among male experienced workers and newly admitted young women- facilitates the relationship among different genders, reproducing at the same time the subordination position that women have." This subordination relationship is reiterated by men and women insisting on the primary maternal role for women. The exclusive attribution of care and reproductive work to worker women contributes to "a pretension of immutability of family arranged roles, so that motherhood constitutes a symbolic frontier limiting the female insertion and development in the mining sector." The authors conclude that "in spite of advances declared by workers of Chuquicamata Division and delays expressed in El Teniente Division, mining companies' institutional policies are still presented as ways of solving problems of "women" or "mothers," excluding the male population in the responsibility of parenting and family and reinforcing the gender imaginary."

An important contribution to the discussion regarding the incorporation of women into the Chilean labor market is developed by the anthropologist Carmen Gloria Godoy, who presents the relevance of meanings attributed to gender equality in the generic configuration of young professional and university women. Based on 25 interviews to middle and upper class women, Godoy analyzes the centrality of a notion of gender equality in the construction of their life projects and daily practices, in family, education and work world.

The normative horizon inspiring women's daily practices in the labor market proves to be a determining factor in their professional trajectories, provided it forms an "ideal type" in relation to which individual performance is evaluated. The author argues that, even though "women's situation in general had improved in relation to the experience of their mothers and grandmothers. 
However, that equality was unfolded differently whether it was in family, work or studies, as well as according to their own family histories." "Family inheritance" in relation to the importance of gender equality has a decisive influence on "the possibility of generating an own life project (oriented towards professional development, maternity or others), in which economic independence is central, appears as one of the main transformations related to the concretion of gender equality, as well as the possibility and the desire to be professionally successful."

The author highlights the intersection of social classes in the perception of women and their role in family, education and labor spheres in Chile, showing that the sense of inadequacy that accompanies women may not be experienced by those who have more economic resources. Godoy states that "the possibility of accessing higher education to develop a professional career inspired by their own parents and having a worker mother as a model, sets a horizon in which work constitutes subjectivity, not completely displacing motherhood thus resisting external definitions of what it means to be a woman and its limits of action."

Finally, work by Villarroel and Sánchez deepens into the conceptualization of female leadership at work. Noting the low female participation at the global concert, authors shed light on presumptions that accompany women who do participate in the labor market at authority roles. According to literature, Villarroel and Sánchez show that values attributed to women's leadership continue to be based on stereotypically female capacities. Authors suggest that the interviews allow "to observe a positive recognition and appreciation of what would be socially feminine, attributing to the leadership characteristic of "being a woman." This would provide a different vision about men, noting that their presence would allow transforming the way of instructing people and the development of organizations in which they participate, a view that mainly emerges from those who exercise female leadership." 
Authors emphasize that, in exercising authority, women' age determines a more authoritarian style of leadership among those older versus a more ideological style among the younger women. However, participation of women in work and in leadership roles continues to be conditioned by assumptions about their "natural" abilities through mediation, dialogue, and teamwork, in what literature has called "maternal forms of leadership."

Contributions of this dossier to understand the dynamics of the labor market that permeate -and limit- women's participation in productive work deepen the analysis on the persistence of defining the feminine as linked to the reproductive and as inherently different from the male contribution: the "soft qualities" of women would balance men's competitiveness and authoritarianism. The insistence on the generic definition of workers is one of the key factors preventing the configuration of the Chilean labor market as a concrete and integral way of social mobility, and as a mechanism of equitable distribution of social resources.

Material and symbolic effects of the crossing of multiple social inequalities are analyzed transversally from the intersectional approach (Crenshaw, 1989, 1991) in the spaces created by gender, territory and social class. In effect, gender and the construction of a sex/gender social system (Rubin, 1996) -binary and hetero-regulated-conditions life experiences as well as the collective imaginary for men and women (Nash, 2014). When gender is conjugated with other variables, such as social class or sexual identity - subverts the aforementioned binary character, it sets new conditions of vulnerability that may involve segregation, social exclusion and multiple violence.

Regarding violence(s), one of the articulating axes of this number, although the institutional framework has offered definitions of gender violence, and violence against women in particular, as a cross-cutting phenomenon for women and girls, it is necessary to distinguish different manifestations and exposition levels to violence by virtue of intersecting social inequalities; for example, 
women, poor, immigrants, black, lesbians, handicapped and so on. In other words, violence against women is related to other forms of violence related to social conditions, such as poverty, marginalization, economic exploitation, so on (Castañeda, Ravelo and Pérez, 2013, p.13).

Geographical particularities within the framework of gender relations offer a reading regarding the conditions of existence of women in different parts of the Globe. Therefore, it is very significant to include in the gender violence axis two researches carried out in Mexico, one of the countries with the highest rates of violence against women and femicide in Latin America. Both articles have in common a critical view against the General Law on Women's Access to a Life Free of Violence (LGAMVLV), enacted in Mexico in 2007, presenting figures of women victims of multiple violence, despite the statistical gaps in this respect, and graphing the institutional resistance to implement prevention mechanisms. Both authors argue that machismo, as a structural dimension, hinders the efficacy of the aforementioned law.

Considering the complexity of the gender violence issue, work by Graciela Vélez and Héctor Serrano contributes to reflecting about from multiple factors affecting violence, as well as analyzing the State prevention and eradication and public policies. The article, based on a contextual diagnosis and interviews to men prosecuted for abuse and/or gender violence, distinguishes elements that allow the visualization of critical nodes hindering progress in terms of prevention, such as lack of an institutional gender approach and resistance to mainstream it. In this way, based on the "ecological model" developed by Bronfenbrenneren, authors propose a comprehensive analysis of gender violence and, consequently, a design of public policies addressing prevention with instruments including a gender focus also aimed at generating equality conditions among men and women.

On the other hand, the article presented by Rocío Rojas proposes an analysis on feminicidal violence in the State of Guana- 
juato and its implications in women life. The methodology used is the analysis of documentary sources through the systematization of femicides appeared in local newspapers and the analysis of secondary data related to gender violence. By virtue of the convergence of this analysis, the work proposes different arguments to explain feminicide, making a conceptual and taxonomic review on types of violence towards women complemented by definitions of feminicide at institutional, legal and academic level. It also identifies the socio-cultural characteristics of Mexico, a country whose patriarchal structure perpetuates traditional gender roles, the subordination of women and with it, violence against women. This work is especially relevant in practice due to the lack of systematized data, despite the increase in crimes against women in the "industrial corridor" sector located in Guanajuato State.

The discussion about violence, as a macro and micro problem visualized in the structural field and also in the social interaction, has its genesis in the asymmetric relations of power among men and women, and in the place of postponement and subordination to female gender. There is vast literature on the public/private distinction in gendered spaces and of different value: men/public and women/private, reflected in dichotomies such as politics and reproduction, or paid work and domestic work (unpaid). In this context, violence comes to underline its relational background, as a relation of power. In the patriarchal order, violence against women demonstrates the attempt to restore the threatened order (Cáceres, 2016), and its symbolic, economic and physical expressions, as well as the most extreme one, such as femicide, provide warning signs social sciences can't ignore.

In another dimension of analysis, the heteronormative support in the differentiation of the public/private social space configures an institutional regime built around difference, which conditions the possibilities of existence of "transgressing subjectivities." A third axis of this number addresses challenges in- 
volved in subverting the norm and how that transgression has effects in the areas of experience, motivations and representations.

The article presented by Paola Contreras addresses personal, family and social consequences experienced by women living maternity in jail. The author emphasizes the experience of these women as a double condemnation: social and criminal. Fundamentally, because they are women whose infringement exceeds the criminal sphere by contravening the ontologized binomial of woman-mother and, consequently, by constituting themselves as "bad mothers," socially judged and sanctioned. The article emphasizes the logic of the penitentiary system that reproduces gender roles and complicates the experience of motherhood. In this way, the historian proposes, from the analysis of critical feminist discourse, a reflection on a series of interviews to women deprived of their freedom in Barcelona, Spain, while they were pregnant, and then, from results, to open a debate that "dismantle" prejudices and stereotypes that these women carry.

In the field of political participation, within the framework of fighting for recognition and sexual and reproductive rights of sexual dissidences, sociologists Catalina Otárola and Catalina Tapia present a research based on the analysis of motivations and experiences, as mutually implicated dimensions, which encourage lesbians to participate in different organizations of the LGBTI+ movement in Chile. The article begins from the assumption that asymmetrical power relations unfold from the gender and influence experiences of subjects and, in this sense, the object of study is implied in a double record: that of the life experience and that of the lesbians' political participation, both in a world historically led by men. In this way, through a qualitative approach, the article provides the possibility of knowing motivations from a logic that goes beyond rationality to emphasize the importance of emotions and values as vectors of political participation.

The analysis carried out by the authors is a contribution to the existing research on subaltern social movements that have 
aroused a special interest within feminist epistemologies, fundamentally for the processes of subalternization developed under the umbrella of broader political agendas, in which gender and various dimensions involved in this analytical category end up in a space of opacity within the framework of political intersectionality (Walby, Armstrong and Strid, 2012; Crenshaw, 1991).

The three thematic axes of the special issue presented here, i.e. labor market, gender violence and normative transgression to women, contribute to evidence, from empirical case studies, that the generic construction is always relational, socio-historical and crossed by power. As Joan Scott has said more than three decades ago: gender is one of the main fields of power articulation, and a facilitator of the significance of power through their mutual construction (1986).

Finally, this dossier closes with two articles related to the two complementary sections in order to shape the complete corpus of Revista Temas Sociológicos Journal. An article by Juan Pablo Venables, "Sociology and Public Opinion: Dismantling a device," reflects about types of power that build realities and public agendas. The article constitutes a significant contribution for understanding the public opinion as an artifact constructed by opinion polls, which legitimize a certain policy and consolidate relations of force that make it possible. Venable shows the need to consider in surveys not only individual beliefs and opinions, but also, "their constraints, sanctions or restrictions, as well as material aspects expressed in actions or practices that give specificity to a social reality." Thus, the author sheds light on the need to explore not only statistics and opinions, but to elucidate the sociopolitical, cultural and economic processes conditioning their perceptions, practices and social positions.

At the end, the review written by sociologists Javiera Osses and Daniela Valencia in reference to the book "Ser Política en Chile" (Being Political in Chile,) by the sociologist and political scientist Julieta Kirkwood, includes in this special issue one of the 
most influential works for feminism in Chile. Almost thirty years after its publication, the analysis about the relationship between women and politics, as well as the invisibility and subalternity of women in a series of social spaces, is still a valid reading and, in this sense, the contribution of this review, recalling one of the most significant women in the field of women and gender studies, is a tribute to her contribution.

Considering gender as a dimension of social inequality materialized in conditions of existence, this dossier wants to relieve social studies about gender that, from a critical paradigm, reach in the Chilean academic and political debate the place granted by the multiplicity of study and research centers and the international human rights system. Increasingly, women's and LGBT+ movements color the streets of the world, highlighting historically opaque demands. Feminist movements in Chile in 2018 warn about experiences of inequality of women and sexual minorities, defying the institutional resistance to incorporate a gender perspective, the discreet protocols against sexual harassment in university institutions and the reduced laws on sexual minorities' and women's human rights, revealing the need to focus on the relationships among gender, power and social inequalities.

\section{References}

Butler, J. (2004). Undoing gender. New York: Routledge.

Cáceres, D. (2016). Sobre la semántica del femicidio en Chile. Sociedad y economía, 239-262.

Castañeda, M., Ravelo, P. and Pérez, T. (2013). Feminicidio y violencia de género en México: omisiones del Estado y exigencia civil de justicia. Iztapalapa Revista de Ciencias Sociales y Humanidades, 74, 11-39.

Crenshaw, K. (1989). Demarginalizing the intersection of Race and Sex: A black Feminist Critique of Antidiscrimination Doctrinem Feminist Theory and Antiracist Politics. University of Chicago Legal Forum, 138-167. 
Crenshaw, K. (1991). Mapping the Margins: intersectionality, identity Politics, and Violence against Women of Color. Stanford Law Review, 1241-1299.

Mansbridge, J. \& Shames, S. L. (2008). Toward a theory of backlash: Dynamic resistance and the central role of power. Politics $\mathcal{E}$ Gender, 4 (4), 623-634.

Mora, C. (2013). Desigualdad en Chile: la continua relevancia del género. Santiago de Chile: Ediciones Universidad Alberto Hurtado.

Nash, M. (Ed). (2014). Feminidades y masculinidades. Madrid: Alianza Editorial.

Rubin, G. (1996). El tráfico de mujeres: notas sobre la "economía política" del sexo, en M. Lamas, El género: la construcción cultural de la diferencia sexual (pp. 35-96). México D.F.: PUEG, Miguel Ángel Porrúa.

Scott, J. (1996). El género como categoría de análisis histórico, en M. Lamas, El género: la construcción cultural de la diferencia sexual (pp. 265-302). México D.F.: PUEG, Miguel Ángel Porrúa.

Valenzuela, M. E. \& Mora, C. (2009). Trabajo doméstico: un largo camino hacia el trabajo decente. Santiago de Chile: International Labor Organization.

Walby, S., Armstrong, J. \& Strid, S. (2012). Instersectionality: Multiple inequalities in Social Theory. Sociology, 224-240. 